\title{
Innovation behaviour in financial services: an empirical analysis
}

\section{Soumodip Sarkar* and Cesaltina Pires}

Department of Management and CEFAGE-UE, Universidade de Évora, Portugal

Email: ssarkar@uevora.pt

Email: cpires@uevora.pt

*Corresponding author

\section{Luísa Carvalho}

Department of Economics and Management and CICE, Setúbal Polytechnic Institute, Portugal Email: lcarvalho@esce.ips.pt

\begin{abstract}
In this paper, using standardised data for over 7000 service sector firms, we test different hypotheses to understand to what extent innovation output and activity in financial sector firms is different from other service firms. An intriguing result for the service sector as a whole is that the effect of a firm being part of a multinational group is negative for product innovation but positive for process innovation. Comparing the innovation behaviour of financial and non-financial services firms, we obtain four very interesting and significant differences. Firstly, we find that financial services have a lower probability of introducing product innovations, but a higher probability of introducing process innovations. Secondly, we find that financial services firms are not particularly good pioneer innovators, but they are quite good as innovation imitators. Thirdly, for the financial services firms, being part of a multinational group increases the probability of the firm being both a pioneer innovator and a product innovator. Finally, we find differences in innovation behaviour due to firm size.
\end{abstract}

Keywords: CIS; financial innovation; financial services; product innovation; process innovation.

Reference to this paper should be made as follows: Sarkar, S., Pires, C. and Carvalho, L. (2008) 'Innovation behaviour in financial services: an empirical analysis', Int. J. Financial Services Management, Vol. 3, Nos. 3/4, pp.223-242.

Biographical notes: Soumodip Sarkar is an Associate Professor in the Department of Management, University of Evora, Portugal. He received his $\mathrm{PhD}$ in Economics from Northeastern University, Boston, in $1995 . \mathrm{He}$ previously worked with the Harvard Institute for International Development (HIID) and later CID, Kennedy School, Harvard University, and is also currently the Director for the Center of Advanced Studies in Management and Economics, (CEFAGE-UE) University of Evora, Portugal. His research interests are international business, innovation and entrepreneurship. He has papers published in several scientific journals and recently published a book on innovation. He is a project leader in Portuguese and European projects, mostly on entrepreneurship and innovation. 